\title{
Grape Rust caused by Phakopsora euvitis, a New Disease for Brazil
}

\author{
Dauri J. Tessmann ${ }^{1}$, José C. Dianese ${ }^{2}$, Werner Genta ${ }^{3}$, João B. Vida ${ }^{1}$ \& Louise L. May-de Mio ${ }^{4}$
}

'Departamento de Agronomia, Universidade Estadual de Maringá, CEP 87020-090, Maringá, PR, e-mail: djtessmann@uem.br; ${ }^{2}$ Departamento de Fitopatologia, Universidade de Brasília, CEP 70910-900 Brasília, DF, e-mail: jcarmine@ unb.br; ${ }^{3}$ Associação Norte Paranaense de Estudos em Fruticultura (ANPEF), CEP 86990-000, Marialva, PR; ${ }^{4}$ Departamento de Fitotecnia e

Fitossanitarismo, Universidade Federal do Paraná, CEP 80035-050, Curitiba, PR

(Aceito para publicação em 13/02/2004)

Autor para correspondência: Dauri J. Tessmann

\section{RESUMO}

Ferrugem da videira caused by Phakopsora euvitis, uma nova doença para 04 Brasil

A ferrugem da videira foi constatada pela primeira vez no Brasil, ocorrendo em parreirais (Vitis spp.)comerciais no estado do
Paraná tendo recentemente atingido também o Estado de São Paulo. O fungo Phakopsora euvitis foi identificado como o agente causal da doença. Esta ferrugem ocorre preferencialmente em folhas maduras causando a desfolha precoce das plantas infetadas.
Recently a bacterial disease of grapes (Vitis spp.) new to the American Tropics was recorded in Brasil (Lima et al., Fitopatol. Bras. 24:440-443. 1999; Malavolta et al., Summa Phytopathol. 25:262-264. 1999), and now a grape rust not known in Brazil was found in Paraná State. In South America, Viégas (Índice de Fungos da América do Sul, IAC, Campinas, 1961) listed on Vitaceae only Phakopsora vitis (Thuem.) Syd. [syn = Angiopsora ampelopsidis (Diet. \& Syd.) Thirum. \& Kern] with incidence on Vitis vinifera L. and V. caribaea DC in Colombia and Venezuela as mentioned by Pearson \& Goheen (Compendium of Grape Diseases, APS Press, St. Paul, MN, 1988).

Pearson \& Goheen (1998) adopted Physopella ampelopsidis (Diet. \& Syd.) Cumm. \& Ramachar [syns: Phakopsora ampelopsidis Diet. \& Syd., Angiopsora ampelopsidis (Diet. \& Syd.) Thirum. \& Kern, Uredo vitis Thüm., U. vialae Lagerh., Physopella vitis Arth.] to designate the grape rust agent, a heteroaecious Uredinales with spermogonia and aecia on Meliosma myriantha Sieb. \& Zucc (Meliosmaceae / Sabiaceae).

Phakopsora ampelopsidis was until recently a fungal complex pathogenic to 22 species distributed in seven genera in family Vitaceae (Ono, Mycologia 92:154-173. 2000). Ono (2000) detected three populations within P. ampelopsidis which were morphologically and pathogenically distinct. The typical P. ampelopsidis formed telia and uredia in Ampelopsidis spp., however the species on Pathernocissus spp. was shown to be $P$. vitis sensu Sydow, and finally the population on Vitis was then shown to be a new Phakopsora species, P. euvitis Ono. A careful observation of the telium and uredium (Figure 1A) formed in grape leaves collected in Brazil indicated that the fungus belongs to $P$. euvitis. Uredinia are hypophyllous, minute, subepidermical, becoming erumpent, surrounded by cylindrical paraphyses 32-55 $\mu \mathrm{m}$ long. Urediniospores 17-28 x 12-18 $\mu \mathrm{m}$ are obovoid, obovoid-ellipsoid or oblong-ellipsoid (Figure 1B). Telia are hypophyllous and subepidermical. Teliospores 14-30 x 8-12 $\mu \mathrm{m}$, generally irregularly arranged in 3-4 layers, oblong, oblong-ellipsoid to cylindrical.
In Brazil, the grape rust was first recorded in a commercial vineyard of table grapes ( $V$. Vinifera $L$.) in Jandaia do Sul, Northwestern Paraná State, in March, 2001. However, a field survey showed that the rust was also present in other counties of Paraná State. In 2003, the fungus also was found in Indaiatuba, Itupeva, Louveira and other areas of State of São Paulo.

The rust symptoms are initially small yellowish pustules containing uredinia, which may coalesce to cover portions of the abaxial leaf surface (Figure 1C). On the adaxial face brown necrotic spots develop opposite to the uredial pustules. Pustules are primarily on mature leaves. In advanced stages of disease development, telia appear as light brown to dark brown protrusions near the uredinia. The rust causes early defoliation of plants.

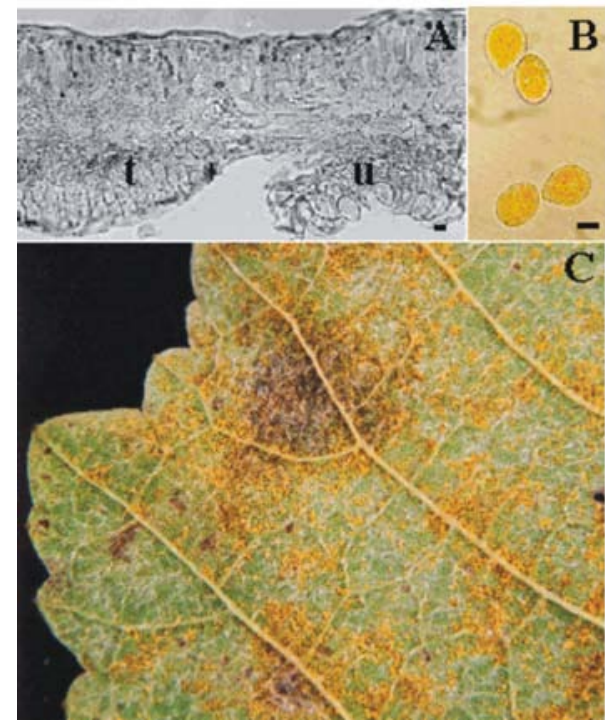

FIG. 1 - Grape (Vitis spp.) rust: A, telium (t) and uredium (u); B, urediniospores; and $\mathrm{C}$, symptoms and signs on leaf. Scale bar $=10$ $\mu \mathrm{m}$ 